\title{
Use of cashew and castor essential oils to improve fibre digestibility in high forage diets: digestibility, ruminal fermentation and microbial protein synthesis
}

\section{Uso de óleos essenciais de caju e mamona para melhorar a digestibilidade da fibra: digestibilidade, fermentação ruminal e síntese de proteína microbiana}

\author{
Roman David Castañeda-Serran ${ }^{1}$; Olga Teresa Barreto-Cruz ${ }^{1 *}$; \\ Sabrina Marcantonio Coneglian²; Antonio Ferriani Branco ${ }^{3}$
}

\begin{abstract}
Highlights:
Cashew and castor essential oils at $2 \mathrm{~g}$ day $^{-1}$ and mixed had enhanced effects. At $2 \mathrm{~g}$ day $^{-1}$ this EO improved fibre digestion in high forage diets.

At lower levels EO could modulate ruminal fermentation, increasing the VFA.
\end{abstract}

\begin{abstract}
High forage diets in the tropics are less efficient and more contaminating due to high energy losses as methane and the low digestibility of tropical forages. The objective of the study was to determine the effects of essential oils (EO) of Anacardium occidentale and Ricinus communis as additives in high forage diets on intake, digestibility, ruminal fermentation and synthesis of microbial protein. Four 'Holstein' steers fitted with ruminal cannula were used in a $4 \times 4$ Latin square design (21-day period). The treatments were 1, 2, 4 and $8 \mathrm{~g} \mathrm{day}^{-1}$ EO per animal (essential oils, Oligobasics ${ }^{\circledR}$ ). The diet was total mixed ration (TMR) of Brachiaria hay (Brachiaria humidicola cv. Lanero) and concentrate (ground corn, soybean meal, ammonium sulphate, urea and minerals) in an 80:20 ratio. Differences were observed in the digestibility of neutral detergent fibre (NDF) and total digestible nutrients (TDN) in levels above $2 \mathrm{~g}_{\text {day }}{ }^{-1} \mathrm{EO}(\mathrm{P}<0.05)$. The VFA (volatile fatty acids) acetate and propionate were higher in diets with $2 \mathrm{~g} \mathrm{day}^{-1} \mathrm{EO}(\mathrm{P}<0.05)$, without affecting the acetate:propionate ratio. Levels above $2 \mathrm{~g}$ day $^{-1} \mathrm{EO}$ negatively affected the faecal $\mathrm{N}$ excretion $(\mathrm{P}<0.05)$. The inclusions of $A$. occidentale and $R$. communis EOs at $2 \mathrm{~g}_{\text {day }}{ }^{-1}$ per day animal improved fibre digestion and decreased $\mathrm{N}$ excretion. These results indicate that this mixture of EOs may have strong antimicrobial activity at lower doses. The $\mathrm{N}$ losses, fibre digestion and digestibility could be improved with the use of cashew and castor essential oils in high forage diets.
\end{abstract}

Key words: Brachiaria humidicola. Biocompounds. Grazing. Methane. Natural additives.

1 Investigadores, Grupo de Investigación en Sistemas Agroforestales Pecuarios, Departamento de Producción Animal, Universidad el Tolima, Ibagué, Tolima, Colômbia.E-mail: rcastaneda@ut.edu.co; otbarretoc@ut.edu.co

$2 \mathrm{Dr}^{\mathrm{a}}$ em Zootecnia, Especialista Técnica, Mosaic Fertilizantes, São Paulo, SP, Brasil. E-mail: sabrina.coneglian@yahoo.com.br

3 Dr. em Zootecnia, Departamento de Zootecnia, Universidade Estadual de Maringá, UEM, Maringá, PR, Brasil. E-mail: afbranco@uem.br

* Author for correspondence 


\section{Resumo}

As dietas no tropico possuem altas proporções de forragem, sendo menos eficientes e mais contaminantes devido às altas perdas de energia na forma de metano e baixa digestibilidade das forragens tropicais. $\mathrm{O}$ objetivo do estudo foi determinar os efeitos dos óleos essenciais (OE) de caju (Anacardium occidentale) e mamona (Ricinus comunis) como aditivos em dietas alto forragem sobre consumo, digestibilidade, fermentação ruminal e síntese de proteína microbiana. Quatro novilhos da raça Holandesa, com cânula ruminal, foram utilizados em delineamento em quadrado latino $4 \mathrm{x} 4$. Os tratamentos foram 1, 2, $4 \mathrm{e}$ $8 \mathrm{~g} \mathrm{dia}^{-1} \mathrm{OE} /$ animal (óleos essenciais - Oligobasics ${ }^{\circledR}$ ). A dieta foi uma ração mista total (TMR) de feno de Brachiaria (Brachiaria humidicola cv Lanero) e concentrado (grão de milho moído, farelo de soja, sulfato de amônio, ureia e minerais) na proporção 80:20. Foram observadas diferenças na digestibilidade da fibra em detergente neutro (FDN) e dos nutrientes digestíveis totais (NDT) em níveis acima de $2 \mathrm{~g} \mathrm{dia}^{-1} \mathrm{OE}(\mathrm{P}<0,05)$. Os AGV (ácidos graxos voláteis) acetato e propionato foram maiores nas dietas com $2 \mathrm{~g} \mathrm{dia}^{-1} \mathrm{OE}(\mathrm{P}<0,05)$, sem afetar a razão acetato: propionato. Níveis acima de $2 \mathrm{~g} \mathrm{dia}^{-1}$ $\mathrm{OE}$ afetaram negativamente a excreção fecal de $\mathrm{N}(\mathrm{P}<0,05)$. As inclusões de $\mathrm{OE}$ de $A$. occidentale e $R$. communis em $2 \mathrm{~g} \mathrm{dia}^{-1} \mathrm{OE} /$ animal melhoraram a digestão da fibra e diminuíram a excreção fecal de $\mathrm{N}$. Estes resultados indicam que esta mistura de $\mathrm{OE}$ pode ter maior atividade antimicrobiana em doses mais baixas. As perdas de N, digestão da fibra e digestibilidade foram melhoradas, com o uso de óleos essenciais de caju e mamona em dietas com alta inclusão de forragem.

Palavras-chave: Aditivos naturais. Brachiaria humidicola. Bio-compostos. Metano. Pastejo.

\section{Introduction}

Tropical pasture-based systems to raise beef cattle are the most common feeding system (Godde, Garnett, Thornton, Ash, \& Herrero, 2018), although forage diets are less efficient (Allen \& de Brauw, 2018) due to the low digestibility of tropical forages and high energy losses in form of methane (Archimède et al., 2011). Tropical pastures are characterised by poorly soluble fibrous fractions and low levels of N (Daiany et al., 2011). Also, to supply energy requirements, proteins in the diet can be fermented as an energy source using the $\mathrm{C}$ skeletons and excreting the nitrogen $(\mathrm{N})$ from the $\mathrm{NH}_{2}$ amino groups(Owens \& Mehmet, 2016).

Biocompounds present in the essential oils (EOs) can modify bacterial cell membrane due to changes in electron transport and the ion gradient, the translocation of proteins, phosphorylation, and other enzyme-dependent reactions, similar to ionophores (Calsamiglia, Busquet, Cardozo, Castillejos, \& Ferret, 2007; McGuffey, 2017) using free $\mathrm{H}^{+}$in ruminal liquid (Cobellis, TrabalzaMarinucci, \& Yu, 2016; Tomkins et al., 2015), thus reducing energy losses by redirecting $\mathrm{H}^{+}$, limiting $\mathrm{CH}_{4}$ formation. Diets that favour a lower acetate: propionate ratio decrease the production of $\mathrm{CH}_{4}$ (Durmic et al., 2014). Poudel, Froehlich, Casper and St-Pierre (2019), in calves fed calf starter pellets and milk replacer supplemented with a commercial blend of EOs (carvacrol, caryophyllene, p-cymene, cineole, terpinene, and thymol) found that propionate concentrations were higher in EO-fed calves compared to controls, and ruminal bacterial communities also differed greatly. The EOs have modulated the degradation of protein and improve fibre digestion in in vitro studies (Lin et al., 2013; Nanon, Suksombat, \& Yang, 2014; Patra \& Yu, 2012)fitted with ruminal and duodenal fistula, were used to investigate the effects of a mixture of essential oils (EO.

Secondary biocompounds of tropical plants can decrease methane production (Goel \& Makkar, 2012). Several compounds with antimicrobial mainly on Gram-positive bacteria (Schären et al., 2017) have been associated with cashew ( $A$. occidentale) and castor (R. communis) (Ajileye, Obuotor, Akinkunmi, \& Aderogba, 2015; Ribeiro, 
Castro, \& Fernandez, 2016) including cardol, cardonol $\beta$-ocimeno, ricinoleic acid and others (Ajileye et al., 2015; Jena \& Gupta, 2012; Kadri, Gharsallah, Damak, \& Gdoura, 2011; Oliveira et al., 2011). Due to the several biocompounds present in Eos, the activity is not mediated by a single mechanism, it is a synergistic and additive effect between biocompounds and the use of EO mixtures can provide a wide spectrum of modulation at low doses (Lv, Liang, Yuan, \& Li, 2011; Tak \& Isman, 2015).

Several in vitro works have shown the effects of the essential oils; however, there is a lack of information to show the effect in vivo, and especially with tropical forage (ex. Brachiaria) with high fibre and low protein content. The objective of this study was to determine the effects of the essential oils (EOs) of A. occidentale and $R$. communis on intake, digestibility, ruminal fermentation, and excretion of purine derivatives in 'Holstein' steers receiving high forage diets.

\section{Material and Methods}

Animals, experimental design, and diets

Four 'Holstein' steers fitted with ruminal cannulae and with average body weights (BW) of $230 \pm 41 \mathrm{~kg}$, housed in individual pens, were fed twice a day with free access to water. A $4 \times 4$ Latin square design was used over four periods (21 days each one). Animals were fed with the same basal diet containing $9.75 \%$ of crude protein (CP), 66.75 $\% \mathrm{~g} \mathrm{~kg}^{-1}$ of neutral detergent fibre (NDF) and 55.60 $\%^{1}$ total digestible nutrients (TDN) on a dry matter (DM) basis according to National Research Council [NRC] (2006) requirements. This constituted of 80 $\%$ of Brachiaria hay (Brachiaria humidicola cv. Lanero) and $20 \%$ of ground corn, soybean meal, urea and minerals concentrate on a DM basis (Table 1). The Essential-Oligobasics ${ }^{\circledR}$, containing $11 \%$ of cardol, $20 \%$ of cardanol and $9 \%$ of ricinoleic acid, were placed daily on the concentrate. Vermiculite was used for the solidification of the essential oils formulated by Oligo Basics Agroindustrial Ltd $^{\circledR}$ (Cascavel, Brazil). Treatments were offered to ensure intake of the following amounts of EOs (Essential oils, Oligobasics ${ }^{\circledR}$ ): 1, 2, 4 and 8 g day $^{-1}$ EO.

\section{Table 1}

Perceptual composition and chemical composition of the total mix ration (TMR) ingredients used in the experimental basal diet on a dry matter (DM) basis

TMR

Ingredient

$\begin{array}{lr}\text { Bracharia hay, \% } & 80.00\end{array}$

Corn meal, \% 14.25

$\begin{array}{ll}\text { Soybean meal, \% } & 3.95\end{array}$

$\begin{array}{lr}\text { Urea, \% } & 0.89\end{array}$

$\begin{array}{lr}\text { Ammonium sulphate, \% } & 0.02\end{array}$

$\begin{array}{lr}\text { Mineral mixture }{ }^{1}, \% & 0.89\end{array}$

Chemical composition

$\begin{array}{ll}\text { Crude protein (CP), \% DM } & 9.75\end{array}$

$\begin{array}{ll}\text { Neutral detergent fibre (NDF), \% DM } & 66.75\end{array}$

$\begin{array}{ll}\text { Ether extract (EE), \% DM } & 2.07\end{array}$

Total digestible nutrients (TDN), \% DM $\quad 55.60$

${ }^{1}$ Calcium: 130,0 g kg-1 (máx.), Phosphorus: 65,0 g kg-1 (min.), Sodium: 135,0 g kg-1 , Sulfur: $12,0 \mathrm{~g} \mathrm{~kg}^{-1}$, Magnesium: 12 g kg-1, Manganese: $1.050 \mathrm{mg} \mathrm{kg}^{-1}$, Cobalt: $63 \mathrm{mg} \mathrm{kg}$, Iodine: $63 \mathrm{mg} \mathrm{kg}$, Copper: $1.155 \mathrm{mg} \mathrm{kg} \mathrm{mg}^{-1}$, Selenium: $18 \mathrm{mg} \mathrm{kg}{ }^{-1}$, Zinc: 3.08 mg $\mathrm{kg}^{-1}$ and Fluor: $650 \mathrm{mg} \mathrm{kg}^{-1}$. 


\section{Intake and digestibility}

Diets were offered twice daily (am/pm). Intake was recorded daily by weighing all the feeds offered to and orts left by the steers. There were $500 \mathrm{~g}$ of samples of feed ingredients and remaining orts collected daily, and they were conserved at $-20{ }^{\circ} \mathrm{C}$ until they were processed by pre-drying in a forced ventilation oven at $55{ }^{\circ} \mathrm{C}$ for 72 hours and milled to $1 \mathrm{~mm}$. The experimental periods lasted for 21 days, with the last four days of each period having the collection at morning samples of feeds, orts left, ruminal fluid, faeces and urine samples. An external indicator containing chromium oxide to estimate faecal output was placed with the concentrate in the morning feed, at a daily dose of $10 \mathrm{~g}^{-1}$ per animal, from the 7th day of each experimental period. Faecal samples $(50 \mathrm{~g})$ in the rectal ampulla were collected on days 18 and 20 of each experimental period, twice daily at alternate times with 4-hour intervals. The chemical composition was determined using Association of Official Analytical Chemists [AOAC] (2016) methods in dry matter number 930.15, crude protein number 992.15 and ether extract number 920.39, and the neutral detergent fibre was determined according to Van Soest, Robertson and Lewis (1991) with the modification of Mertens (2002). Faecal chromium was determined by atomic absorption spectrophotometry (Williams, David, \& Iismaa, 1962) and then used together with the nutrient concentration to determine the flow of nutrients in the faeces. The TDN was calculated according to the equations proposed by Sniffen, O’Connor, Van Soest, Fox and Russell.

\section{Ruminal fermentation}

Samples were collected at 2, 4, 6 and $8 \mathrm{~h}$ after the first feeding. Ruminal fluid was collected through a ruminal cannula using a vacuum pump. Samples of $150 \mathrm{~mL}$ were withdrawn. The $\mathrm{pH}$ of the ruminal fluid was measured immediately after sampling (Digimed DM20 pH meter). Samples of $50 \mathrm{~mL}$ were acidified with $50 \% \mathrm{H}_{2} \mathrm{SO}_{4}(1: 1)$ and frozen at $-20{ }^{\circ} \mathrm{C}$ for later determination of voltaic fatty acids (VFA) and ammonia $\mathrm{N}\left(\mathrm{NH}_{3}-\mathrm{N}\right)$ concentrations. Rumen fluid was taken from the middle part of the rumen by a stomach tube connected to a vacuum pump and then filtered through layers of cheesecloth. The concentration of $\mathrm{NH}_{3}-\mathrm{N}$ of samples was measured by a colourimetric method according to Chaney and Marbach (1962). About $30 \mathrm{~mL}$ were centrifuged for $15 \mathrm{~min}$ at $4000 \times \mathrm{g}$. To $5 \mathrm{~mL}$ of supernatant, $1 \mathrm{~mL}$ of $250 \mu \mathrm{L}$ metaphosphoric acid was added. After 30 min, if a precipitate formed, it was removed by a brief centrifuging. The determination of VFA was made in GLC (Hewlett Packard 5890 Series II GC) according to the methodology of Playne (1985).

\section{Purine derivatives}

Sample spots of urine were collected on days 19 and 20 of each experimental period, 3 to $4 \mathrm{~h}$ after the first feeding, during spontaneous urination.

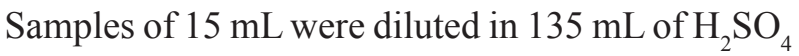
with $0.036 \mathrm{~N}$ (Chen, Mejia, Kyle, \& Ørskov, 1995) and adjusted to a $\mathrm{pH}$ of less than 3 to avoid bacterial destruction of purine derivatives; these were then stored at $-20^{\circ} \mathrm{C}$. The total daily urine volume was estimated according to the creatinine concentration $(\mathrm{mg} / \mathrm{L})$ in the urine spot sample. This volume was then used to estimate the daily excretions of allantoin and uric acid from each animal. The uric acid, xanthine and hypoxanthine analyses were performed according to Chen, Methieson, DeB Hovel and Reeds (1990). The urine allantoin analyses were performed using the colourimetric method (Chen \& Gomes, 1992; Fujihara, Ørskov, Reeds, \& Kyle, 1987). Estimates of creatinine and uric acid concentrations in urine were performed using commercial Labtest ${ }^{\circledR}$ kits. 


\section{Statistical analysis}

The experimental design was a $4 \times 4$ Latin Square. An ANOVA was performed using the mixed model methodology in MINITAB 17'TM (2014). For variables that were repeated over time, a splitplot arrangement was used (subdivided plots), considering the effect of time and the interaction between time and treatment. The mathematical model used included period, treatment and animal effects, which were considered as random: Yijk $=\mu+A i+P j+T k+e i j k$, where $\mu=$ mean of treatments; $A i=$ effect of animal i, ranging from 1 to $4 ; P j=$ effect of period $j$, ranging from 1 to $4 ; T k$
$=$ effect of treatment $k$, ranging from 1 to 5 ; eijk $=$ random error. Significant differences were accepted between treatments if $\mathrm{P} \leq 0.05$ by the Fisher test.

\section{Results and Discussion}

No differences were observed for the inclusions of EO (P > 0.05) on intake among treatments (Table $2)$. In the total apparent digestibility, the neutral detergent fibre (NDF) and total digestible nutrients (TDN) at the level of $2 \mathrm{~g} \mathrm{day}^{-1} \mathrm{EO}$ had the highest observed digestibility in comparison with the other treatments $(\mathrm{P}<0.05)$.

Table 2

Intake and nutrient apparent total tract digestibility in 'Holstein' steers supplemented with increasing levels of cashew (A. occidentale) and castor (R. communis) EOs in a high forage diet

\begin{tabular}{|c|c|c|c|c|c|c|}
\hline \multicolumn{6}{|c|}{${ }^{+}$EO Inclusions g day ${ }^{-1}$} & \multirow[t]{2}{*}{ P-Valuc } \\
\hline Item & 1 & 2 & 4 & 8 & SEM $^{1}$ & \\
\hline \multicolumn{7}{|c|}{ Intake $\mathrm{kg}^{-1}$} \\
\hline Dry matter & 4.50 & 4.64 & 4.56 & 4.41 & 0.30 & 0.953 \\
\hline Crude Protein & 0.46 & 0.46 & 0.47 & 0.43 & 0.03 & 0.797 \\
\hline Neutral detergent fibre & 3.26 & 3.37 & 3.29 & 3.21 & 0.24 & 0.971 \\
\hline \multirow[t]{2}{*}{ Ether extract } & 0.04 & 0.04 & 0.04 & 0.04 & 0.10 & 0.968 \\
\hline & \multicolumn{4}{|c|}{ Digestibility, \% } & & \\
\hline Dry matter & 51.45 & 58.31 & 52.36 & 49.71 & 3.69 & 0.419 \\
\hline Crude Protein & 63.06 & 68.77 & 58.16 & 56.58 & 4.55 & 0.278 \\
\hline Neutral detergent fibre & $48.80 \mathrm{~b}$ & $57.81 \mathrm{a}$ & $51.20 \mathrm{ab}$ & $49.76 b$ & 2.40 & 0.035 \\
\hline Ether extract & 72.57 & 76.89 & 63.47 & 63.98 & 7.27 & 0.280 \\
\hline $\mathrm{TDN}^{2}$ & $56.68 \mathrm{~b}$ & $64.26 \mathrm{a}$ & $57.90 \mathrm{~b}$ & $54.96 \mathrm{~b}$ & 2.05 & 0.004 \\
\hline
\end{tabular}

${ }^{1} \mathrm{SEM}$ : standard error of means. ${ }^{2} \mathrm{TDN}=$ total digestible nutrients. ${ }^{+}$Essential oil containing $11 \%$ of cardol, $20 \%$ of cardanol and $9 \%$ of ricinoleic acid. Means with different letters have statistic differences by Fisher test.

In the digestibility, consequently, with the high digestion of fibre, the total digestible nutrients
(TDN) in levels above $2 \mathrm{EO} g$ day presented the highest values $(\mathrm{P}<0.05)$ (Figures 1 and 2$)$. 


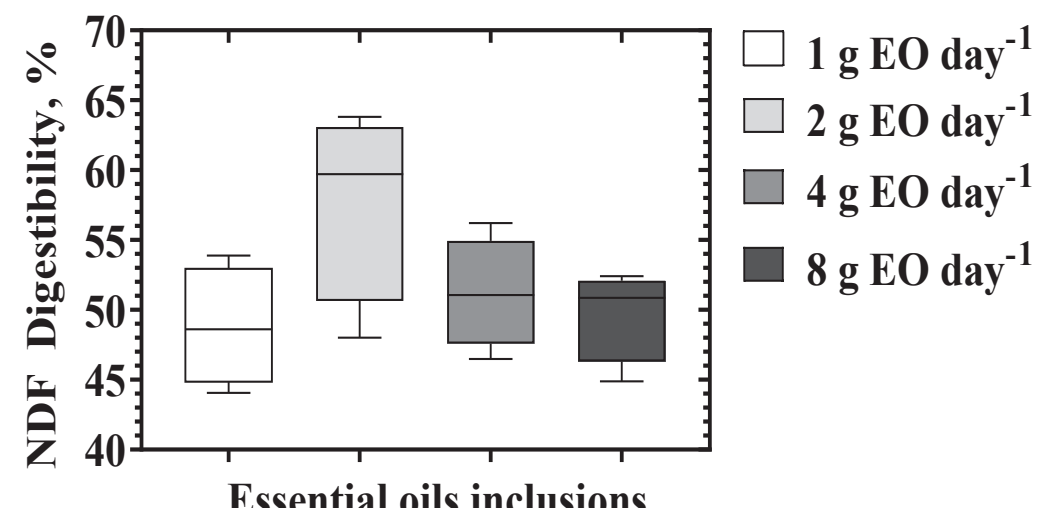

Figure 1. NDF (Neutral detergent fibre) digestibility in Holsteins steers supplemented with increasing levels of EO of $A$. occidentale and $R$. comunnis in high forage diet.

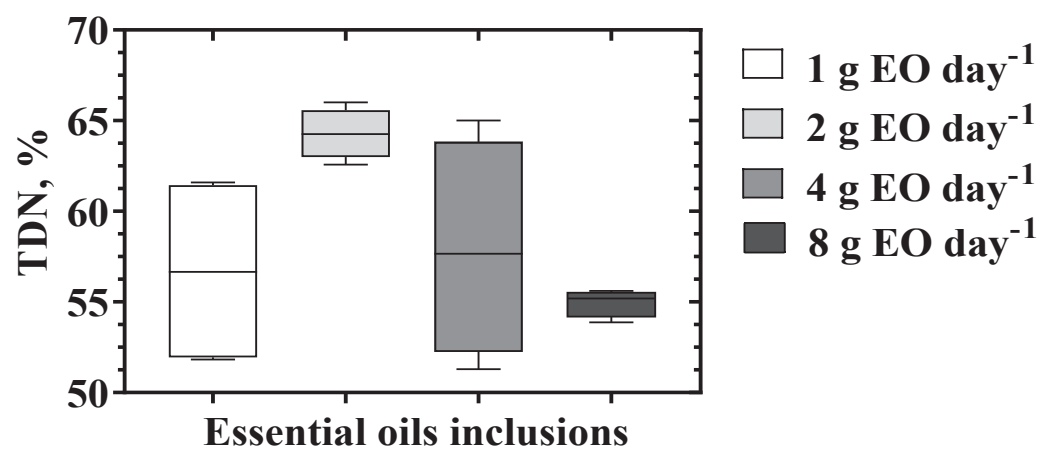

Figure 2. TDN (total digestible nutrients) in Holsteins steers supplemented with increasing levels of EO of $A$. occidentale and $R$. comunnis in high forage diet.

Similarly to Michailoff et al. (2020) in sheep with rumen cannulation in a $4 \times 4$ Latin square, using 2, 4, and $6 \mathrm{EO} \mathrm{g}$ day $^{-1}$ of Cashew and castor oil, found that intake of digestible organic matter decreased linearly with the inclusion of EO, and at 2 and 4 EO $g$ day ${ }^{-1}$, the treatments did not affect nutrient digestibility. Teobaldo et al. (2020), also found in grazing beef cattle cannulated in a $4 \times 4$ Latin-square, using a blend of cashew, castor, and copaiba EOs, at 150,300 and $450 \mathrm{mg} \mathrm{kg}^{-1}$ of DM in comparison with $150 \mathrm{mg} \mathrm{kg}^{-1} \mathrm{DM}$ of monensin, that in the lower concentration (EO 150) increased NDF digestibility and improved nitrogen utilisation efficiency.
Essential oils could be more efficient at lower doses; high doses could negatively affect digestibility (Benchaar, Duynisveld, \& Charmley, 2006), due to an effect on the ruminal population. Patra \& Yu, (2012), evaluated five EOs: clove, eucalyptus, garlic, oregano and mint in different levels in three doses in vitro $\left(0,25,0.50\right.$ and $\left.1.0 \mathrm{~g} \mathrm{~L}^{-1}\right)$, and observed negative effects on the digestibility of DM and fibre in the high doses since the EOs decreased the abundance of Archaea, protozoa and cellulolytic bacteria.

The effectiveness of cashew (A. occidentale) and castor ( $R$. communis) EOs may be greater at lower doses and as a mixture. In the present study at 2 
$\mathrm{g}^{-1} \mathrm{EO}$, fibre and TDN digestibility were improved in tropical diets with high forage proportion, in comparison with doses of 1, 4, 8 EO g day ${ }^{-1}$.

No effects of the inclusion levels of EO were observed on the $\mathrm{pH}$ and $\mathrm{NH}_{3}-\mathrm{N}$ at the ruminal level $(\mathrm{P}>0.05)$ (Table 3). However, in the VFA, acetate and propionate, differences were observed among treatments $(\mathrm{P}<0.05)$, without affecting the acetate:propionate ratio. The total VFA and propionate were higher in diets with $2 \mathrm{~g}$ day $^{-1} \mathrm{EO}$, and the ruminal $\mathrm{pH}$ remained at an average of 6.7.

The total VFA increased at the level of $2 \mathrm{~g} \mathrm{day}^{-1}$ EO. According to the substrate of fermentation, the VFA production could be affected. The content of fibre in the diet affects the metabolism of cellulose, degradation and VFA production (Wang, Zhang, Li, \& Zhang, 2020), and high forage diets decreased VFA concentration (Penner, Taniguchi, Guan, Beauchemin, \& Oba, 2009). The type of diet, fibrous or concentrated, has a direct impact on the use of EO (Coneglian, Castañeda Serrano, Cruz, \& Branco, 2019; Molero, Ibars, Calsamiglia, Ferret, \& Losa, 2004), due to the retention time of particles of the diet (Owens \& Mehmet, 2016), and feedparticle binding properties of rumen microbiota that differs according to diet substrate (Kim, Eastridge,
\& Yu, 2014)both alone and together with dietary fat, on ruminal bacterial communities in dairy cattle fed the following 3 diets: a control diet, the control diet supplemented with monensin, and the control diet supplemented with both monensin and fat. Bacterial communities in the liquid and the adherent fractions of rumen content were analyzed using 454 pyrosequencing analysis of 16S rRNA gene amplicons. Most sequences were assigned to phyla Firmicutes and Bacteroidetes, irrespective of diets and fractions. Prevotella was the most dominant genus, but most sequences could not be classified at the genus level. The proportion of Gram-positive Firmicutes was reduced by $4.5 \%$ in response to monensin but increased by $12.8 \%$ by combination of monensin and fat, compared with the control diet. Some of the operational taxonomic units in Firmicutes and Bacteroidetes were also affected by monensin or by the combination of monensin with fat. The proportion of numerous bacteria potentially involved in lipolysis and (or.The EOs have a greater potential to exert a positive effect on fibrous substrates, due to a higher retention rate at the ruminal level (Dijkstra, France, \& Davies, 1998). A longer time to expose of EOs could lead to major effects on the fibre-associated rumen microbiota.

Table 3

Ruminal fermentation characteristics in 'Holstein' steers with increasing levels of cashew (A. occidentale) and castor (R. communis) EOs in a high forage diet

\begin{tabular}{|c|c|c|c|c|c|c|}
\hline \multirow[b]{2}{*}{ Item } & \multicolumn{4}{|c|}{${ }^{+}$EO Inclusions $\mathrm{g}$ day ${ }^{-1}$} & \multirow[b]{2}{*}{$\mathrm{SEM}^{1}$} & \multirow{2}{*}{ P-Value } \\
\hline & 1 & 2 & 4 & 8 & & \\
\hline $\mathrm{pH}$ & 6.72 & 6.71 & 6.71 & 6.70 & 0.10 & 0.938 \\
\hline $\mathrm{NH}_{3}-\mathrm{N}, \mathrm{mg} 100 \mathrm{~mL}^{-1}$ & 12.68 & 13.20 & 10.79 & 11.98 & 1.56 & 0.721 \\
\hline \multicolumn{7}{|l|}{ VFA, mM L-1 } \\
\hline Acetate & $40.12 b$ & $44.06 \mathrm{a}$ & $40.70 \mathrm{~b}$ & $42.59 \mathrm{ab}$ & 1.10 & 0.051 \\
\hline Propionate & $13.35 b$ & $15.10 \mathrm{a}$ & $13.62 b$ & $14.04 \mathrm{~b}$ & 0.33 & 0.001 \\
\hline Butyrate & $6.86 \mathrm{c}$ & $8.03 a$ & $7.35 \mathrm{bc}$ & 7.78ab & 0.23 & 0.002 \\
\hline Acetate:propionate & 3.02 & 2.93 & 3.01 & 3.05 & 0.06 & 0.560 \\
\hline
\end{tabular}

${ }^{1}$ SEM: standard error of means. ${ }^{+}$Essential oil containing $11 \%$ of cardol, $20 \%$ of cardanol and $9 \%$ of ricinoleic acid. Means with different letters have statistic differences by Fisher test. 
Most of the EO compounds at high doses have demonstrated their antimicrobial activity by decreasing total VFA concentration (Kahvand \& Malecky, 2018). Teobaldo et al. (2020), in in vitro experiment using a gas-production (GP) system, with inclusions of a blend of EOs (copaiba, cashew and castor oils), found at low doses (150 mg kg-1 $\mathrm{DM})$ an improvement in ruminal fermentation, but the medium (300 $\mathrm{mg} \mathrm{kg}^{-1} \mathrm{DM}$ ) and high (450 $\mathrm{mg} \mathrm{kg}^{-1}$ DM) doses of EOs decreased gas production at 12 and $24 \mathrm{~h}$ and decreased DM and NDF digestibility at $48 \mathrm{~h}$ compared with the control, Monensina (150 $\mathrm{mg} \mathrm{kg}{ }^{-1} \mathrm{DM}$ ) and $150 \mathrm{mg} \mathrm{kg}^{-1}$ EO DM

Nevertheless, Tomkins et al. (2015), in beef cattle fed medium- to low-quality Rhodes grass (Chloris gayana) hay using a specific blend of essential oils (CRINA ${ }^{\circledR}$ Ruminants at $1 \mathrm{~g}$ per day) in a $5 \times 5$ Latin square, found that EOs significantly increased butyrate and iso-valerate concentrations compared with the control. This suggests that at low levels of EO could improve the VFA concentration.

Akbarian-Tefaghi, Ghasemi and Khorvash (2018), in calves using a blend of EO (containing carvacrol, thymol and limonene), found an increase of molar proportions of acetate and butyratel as well as the acetate: propionate ratio. A higher acetate:propionate ratio is related to the highest glucose concentration and $\beta$-hydroxyl butyrate.

Elcoso, Zweifel and Bach (2019), supplemented 48 Holstein cows with commercial EO Agolin (coriander, eugenol, and geranyl acetate) at $1 \mathrm{~g}$ day $^{-1}$, and they found enhanced milk production attributed to an improvement of rumen fermentation by decreases in rumen methane production.

According to our results, the production of propionate improved without affecting the acetate:propionate ratio. Additives could modulate ruminal fermentation, not only by a direct effect of the ruminal population but also through a decrease in substrate availability (Schären et al., 2017). An increase in propionic acid can lead to a reduction in methane (Jouany \& Morgavi, 2007). In tropical diets, methane production is elevated (Godde et al., 2018), and the use of cashew and castor EOs could modulate the methane production and energy efficiency, improving ruminal fermentation.

The N Balance and the synthesis of microbial protein were not affected by the inclusion of EO (P $>0.05$ ) (Table 4). Nevertheless, among treatments, a tendency was observed in levels above $2 \mathrm{~g}$ day $^{-1}$ EO affected faecal $\mathrm{N}$ excretion $(\mathrm{P}<0.062)$.

\section{Table 4}

Excretion of urinary purine derivatives (PD) and microbial N supply in 'Holstein' steers supplemented with increasing levels of cashew (A. occidentale) and castor ( $R$. communis) EOs in a high forage diet

\begin{tabular}{|c|c|c|c|c|c|c|}
\hline \multicolumn{6}{|c|}{${ }^{+}$EO Inclusions g day ${ }^{-1}$} & \multirow{2}{*}{ P-Value } \\
\hline Item & 1 & 2 & 4 & 8 & SEM $^{1}$ & \\
\hline $\mathrm{N}$ intake, $\mathrm{g} \mathrm{day}^{-1}$ & 73.51 & 74.32 & 74.45 & 68.69 & 4.87 & 0.814 \\
\hline Faecal N, g day ${ }^{-1}$ & 24.32 & 23.50 & 28.28 & 34.28 & 2.79 & 0.062 \\
\hline $\mathrm{BUN}^{2}, \mathrm{mg} \mathrm{dl}^{-1}$ & 13.39 & 12.51 & 11.44 & 12.37 & 0.76 & 0.575 \\
\hline Allantoin excretion mmol day ${ }^{-1}$ & 112.96 & 121.54 & 107.67 & 120.24 & 14.25 & 0.916 \\
\hline Uric acid excretion mmol day ${ }^{-1}$ & 3.51 & 3.36 & 2.62 & 2.77 & 0.55 & 0.594 \\
\hline $\mathrm{PD}^{3}$, mmol day $^{-1}$ & 116.47 & 124.90 & 110.29 & 123.01 & 14.18 & 0.912 \\
\hline Microbial protein $\mathrm{g}$ of $\mathrm{N}$ day ${ }^{-1}$ & 80.62 & 87.72 & 75.38 & 86.09 & 11.88 & 0.912 \\
\hline $\mathrm{EMPS}^{4}, \mathrm{~g} \mathrm{CP} \mathrm{kg} \mathrm{TDN}^{-1}$ & 100.01 & 114.44 & 99.92 & 114.62 & 15.78 & 0.880 \\
\hline
\end{tabular}

${ }^{1} \mathrm{SEM}$ : standard error of means. ${ }^{2} \mathrm{BUN}$ : Blood urea nitrogen; ${ }^{3} \mathrm{PD}$ : Purine derivates; ${ }^{4} \mathrm{EMPS}=$ efficiency of microbial protein synthesis. ${ }^{+}$Essential oil containing $11 \%$ of cardol, $20 \%$ of cardanol and $9 \%$ of ricinoleic acid. Means with different letters have statistic differences by Fisher test. 
Levels above $2 \mathrm{~g}$ day $^{-1} \mathrm{EO}$ per day showed a negative effect on the balance of $\mathrm{N}$, increasing the faecal excretion (Figure 3.)

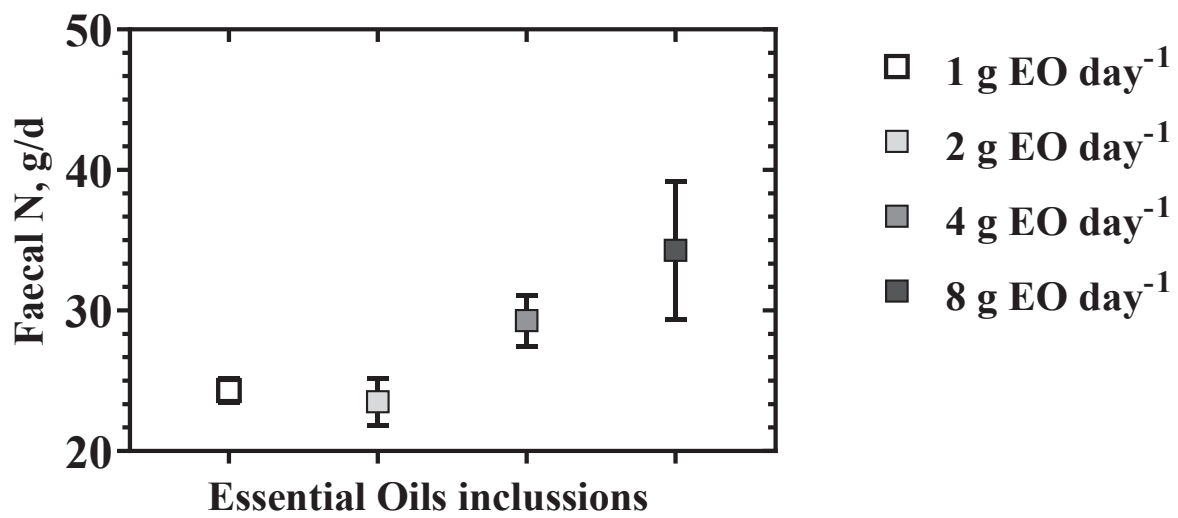

Figure 3. Faecal N, g/d in Holsteins steers supplemented with increasing levels of $\mathrm{EO}$ of $A$. occidentale and $R$. comunnis in high forage diet.

Molero et al. (2004), using a blend of essential oils, found that EOs in the high concentratediet tended to reduce $\mathrm{CP}$ degradation of soybean meal. However, Newbold, McIntosh, Williams, Losa and Wallace (2004), in high forage diets, found that EO inhibited ruminal degradation ofsoybean meal $\mathrm{N}$ but not heat-treated rapeseed meal or hay. The EO could inhibita specific ruminal population that results in an inhibition of deamination andmethanogenesis, resulting in lower ammonia $\mathrm{N}$, methane, and acetate, and higher propionateand butyrate concentrations (Calsamiglia et al., 2007; Torres, Moura, Ghedini, Ezequiel and Almeida, 2020). In the present study, cashew and castor EOs at high levels tended toaffect $\mathrm{N}$ balance, promoting $\mathrm{N}$ escape in faeces without effect on synthesis ofmicrobial protein. According to Oh, Harper and Hristov (2019), it is plausible that low doses of secondary metabolites present intropical plants can have positive effects on the host animal through postruminal mechanisms rather than effects on the rumen microbiota.

The allantoin:purine derivatives ratio was more than $90 \%$, considered higher than Chen and Gomes, (1992), who had ranges from 80 to $85 \%$. Relative to the proportion of uric acidin the purine derivatives, Chen and Gomes (1992) considered the ideal value to be 15 to $20 \%$, which is considered constantin one animal, but variable among the animals. In this experiment, the ratio ofuric acid to purine derivatives was $40 \%$. The microbial protein synthesis efficiencywas $107 \mathrm{~g} \mathrm{~kg}^{-1}$ of CP per TDN and was below the NRC (2006). However, InLow-TDN diets might reduce passage rate and microbial efficiency.

\section{Conclusions}

Inclusions of $2 \mathrm{~g}^{\text {day }}{ }^{-1}$ of of cashew and castor EOs increased the fibre digestibility, the propionate production, and control the rate of $\mathrm{N}$ excretion.

These results indicate that these EOs could improve digestibility, reducing potential energy losses by redirecting $\mathrm{H}+$ for a higher propionate formation and control the fermentation rate of the protein in diets with a high tropical forage ratio.

Further studies are necessary to evaluate the level in $\mathrm{g} \mathrm{day}^{-1}$ to reach the potential of these essential oils in the diet to avoid negative effects at high doses. 


\section{References}

Ajileye, O. O., Obuotor, E. M., Akinkunmi, E. O., \& Aderogba, M. A. (2015). Isolation and characterization of antioxidant and antimicrobial compounds from Anacardium occidentale L. (Anacardiaceae) leaf extract. Journal of King Saud University - Science, 27(3), 244-252. doi: 10.1016/j. jksus.2014.12.004

Akbarian-Tefaghi, M., Ghasemi, E., \& Khorvash, M. (2018). Performance, rumen fermentation and blood metabolites of dairy calves fed starter mixtures supplemented with herbal plants, essential oils or monensin. Journal of Animal Physiology and Animal Nutrition, 102(3), 630-638. doi: 10.1111/jpn.128 42

Allen, S., \& de Brauw, A. (2018). Nutrition sensitive value chains: theory, progress, and open questions. Global Food Security, 16, 22-28. doi: 10.1016/j. gfs.2017.07.002

Association of Official Analytical Chemists (2016). Official methods of analysis of AOAC international. Gaithersburg: J. George Latimer.

Archimède, H., Eugène, M., Marie Magdeleine, C., Boval, M., Martin, C., Morgavi, D. P.,... Doreau, M. (2011). Comparison of methane production between C3 and C4 grasses and legumes. Animal Feed Science and Technology, 166, 59-64. doi: 10.1016/j. anifeedsci.2011.04.003

Benchaar, C., Duynisveld, J. L., \& Charmley, E. (2006). Effects of monensin and increasing dose levels of a mixture of essential oil compounds on intake, digestion and growth performance of beef cattle. Canadian Journal of Animal Science, 86 (1), 91-96. doi: 10.4141/A05-027

Calsamiglia, S., Busquet, M., Cardozo, P. W., Castillejos, L., \& Ferret, A. (2007). Invited review: essential oils as modifiers of rumen microbial fermentation. Journal of Dairy Science, 90(6), 2580-2595. doi: 10. 3168/jds.2006-644

Chaney, A. L., \& Marbach, E. P. (1962). Modified reagents for determination of urea and ammonia. Clinical Chemistry, 8(2), 130-132. doi: 10.1021/ AC60252A045

Chen, X. B., \& Gomes, M. J. (1992). Estimation of microbial protein supply to sheep and cattle basid on urinary excretion of purine derivatives-an overview of the technical details. Buchsburnd, Aberdeen: Ed. Rowett Research Institute.

Chen, X. B., Mejia, A. T., Kyle, D. J., \& Ørskov, E. R. (1995). Evaluation of the use of the purine derivative- creatinine ratio in spot urine and plasma samples as an index of microbial protein supply in ruminants - studies in sheep. Journal of Agricultural Science, 125(1), 137-143. doi: 10.1017/S002185960007458X

Chen, X. B., Methieson, J., DeB Hovel, F., \& Reeds, P. J. (1990). Measurement of purine derivative in urine of ruminants using automated methods. Journal of the Science of Food and Agriculture, 53(1), 23-33. doi: 10.1002/jsfa.2740530104

Cobellis, G., Trabalza-Marinucci, M., \& Yu, Z. (2016). Science of the total environment critical evaluation of essential oils as rumen modi fi ers in ruminant nutrition : a review. Science of the Total Environment, 546, 556-568. doi: 10.1016/j.scitotenv.2015.12.103

Coneglian, S. M., Castañeda Serrano, R. D., Cruz, O. T. B., \& Branco, A. F. (2019). Effects of essential oils of Cashew and Castor on intake, digestibility, ruminal fermentation and purine derivatives in beef cattle fed high grain diets. Semina: Ciências Agrárias, 40(5), 2057. doi: 10.5433/1679-0359.2019v40n5p2057

Daiany, G., Detmann, E., Valadares, S. D. C., F ${ }^{\circ}$, Fukushima, R. S., Souza, M. A. de, Valente, T. N. P., ... Queiroz, A. C. de. (2011). Evaluation of lignin contents in tropical forages using different analytical methods and their correlations with degradation of insoluble fiber. Animal Feed Science and Technology, 168(3-4), 206-222. doi: 10.1016/j. anifeedsci.2011.05.001

Dijkstra, J. A. N., France, J., \& Davies, D. R. (1998). Different mathematical approaches to estimating microbial protein supply in ruminants. Journal of Dairy Science, 81(12), 3370-3384. doi: 10.3168/jds. S0022-0302(98)75902-8

Durmic, Z., Moate, P. J., Eckard, R., Revell, D. K., Williams, R., \& Vercoe, P. E. (2014). In vitro screening of selected feed additives, plant essential oils and plant extracts for rumen methane mitigation. Journal of the Science of Food and Agriculture, 94(6), 1191-1196. doi: 10.1002/jsfa.6396

Elcoso, G., Zweifel, B., \& Bach, A. (2019). Effects of a blend of essential oils on milk yield and feed efficiency of lactating dairy cows. Applied Animal Science, 35(3), 304-311. doi: 10.15232/aas.2018-01 825

Fujihara, T., Ørskov, E. R., Reeds, P. J., \& Kyle, D. J. (1987). The effect of protein infusion on urinary excretion of purine derivatives in ruminants nourished by intragastric nutrition. The Journal of Agricultural Science, 109(1), 7-12. doi: 10.1017/ S0021859600080916 
Godde, C. M., Garnett, T., Thornton, P. K., Ash, A. J., \& Herrero, M. (2018). Grazing systems expansion and intensification: Drivers, dynamics, and trade-offs. Global Food Security, 16, 93-105. doi: 10.1016/ j.gfs.2017.11.003

Goel, G., \& Makkar, H. P. S. (2012). Methane mitigation from ruminants using tannins and saponins. Tropical animal health and production, 44(4), 729-739. doi: 10.1007/s11250-011-9966-2

Jena, J., \& Gupta, A. K. (2012). Ricinus communis linn: a phytopharmacological review. International Journal of Pharmacy and Pharmaceutical Sciences, 4(4), 25-29.

Jouany, J.-P., \& Morgavi, D. P. (2007). Use of 'natural' products as alternatives to antibiotic feed additives in ruminant production. Animal, 1(10), 1443-1466. doi: 10.1017/S1751731107000742

Kadri, A., Gharsallah, N., Damak, M., \& Gdoura, R. (2011). Chemical composition and in vitro antioxidant properties of essential oil of Ricinus communis L. Journal of Medicinal Plants Research, 5(8), 1466-1470. doi: 10.5897/JMPR.9000347

Kahvand, M., \& Malecky, M. (2018). Dose-response effects of sage (Salvia officinalis) and yarrow (Achillea millefolium) essential oils on rumen fermentation in vitro. Annals of Animal Science, 18(1), 125-142. doi: 10.1515/aoas-2017-0024

Kim, M., Eastridge, M. L., \& Yu, Z. (2014). Investigation of ruminal bacterial diversity in dairy cattle fed supplementary monensin alone and in combination with fat, using pyrosequencing analysis. Canadian Journal of Microbiology, 60(2), 65-71. doi: 10.1139/ cjm-2013-0746

Lin, B., Lu, Y., Salem, A. Z. M., Wang, J. H., Liang, Q., \& Liu, J. X. (2013). Effects of essential oil combinations on sheep ruminal fermentation and digestibility of a diet with fumarate included. Animal Feed Science and Technology, 184(1-4), 24-32. doi: 10.1016/j.anifeedsci.2013.05.011

Lv, F., Liang, H., Yuan, Q., \& Li, C. (2011). In vitro antimicrobial effects and mechanism of action of selected plant essential oil combinations against four food-related microorganisms. Food Research International, 44(9), 3057-3064. doi: 10.1016/j. foodres.2011.07.030

McGuffey, R. K. (2017). A 100-year review: metabolic modifiers in dairy cattle nutrition. Journal of Dairy Science, 100(12), 10113-10142. doi: 10.3168/ jds.2017-12987
Mertens, D. R. (2002). Gravimetric determination of amylase-treated neutral detergent fiber in feeds with refluxing in beakers or crucibles: ollaborative study. Journal of AOAC International, 85(6), 1217-1240. doi: $10.1093 /$ jaoac/85.6.1217

Michailoff, A. A., Silveira, M. F., Maeda, E. M., Sordi, A. C. B., Francisco, L. F., \& Farenzena, R. (2020). Effect of including functional oils in ovine diets on ruminal fermentation and performance. Small Ruminant Research, 185, 106084. doi: 10.1016/j. smallrumres.2020.106084

Molero, R., Ibars, M., Calsamiglia, S., Ferret, A., \& Losa, R. (2004). Effects of a specific blend of essential oil compounds on dry matter and crude protein degradability in heifers fed diets with different forage to concentrate ratios. Animal Feed Science and Technology, 114(1-4), 91-104. doi: 10.1016/j. anifeedsci. 2003.11.011

Nanon, A., Suksombat, W., \& Yang, W. Z. (2014). Effects of essential oils supplementation on in vitro and in situ feed digestion in beef cattle. Animal Feed Science and Technology, 196, 50-59. doi: 10.1016/j. anifeedsci.2014.07.006

National Research Council (2006). Nutrient requirements of beef cattle.

Newbold, C. J., McIntosh, F. M., Williams, P., Losa, R., \& Wallace, R. J. (2004). Effects of a specific blend of essential oil compounds on rumen fermentation. Animal Feed Science and Technology, 114(1-4), 105112. doi: 10.1016/j.anifeedsci.2003.12.006

Oh, J., Harper, M., \& Hristov, A. N. (2019). Effects of lowering crude protein supply alone or in a combination with essential oils on productivity, rumen function and nutrient utilization in dairy cows. Animal, 13(11), 50-59 1-9. doi: 10.1017/ S1751731119001083

Oliveira, M. S. C., Morais, S. M. de, Magalhães, D. V., Batista, W. P., Vieira, Í. G. P., Craveiro, A. A.,... Lima, G. P. G. de. (2011). Antioxidant, larvicidal and antiacetylcholinesterase activities of cashew nut shell liquid constituents. Acta Tropica, 117(3), 165170. doi: 10.1016/j.actatropica.2010.08.003

Owens, F. N., \& Mehmet, B. (2016). Ruminal Fermentation. In Rumenology (pp. 63-102). Springer, Cham. doi: 10.1007/978-3-319-30533-2

Patra, A. K., \& Yu, Z. (2012). Effects of essential oils on methane production and fermentation by, and abundance and diversity of, rumen microbial populations. Applied and Environmental Microbiology, 78(12), 4271-4280. doi: 10.1128/ AEM.00309-12 
Penner, G. B., Taniguchi, M., Guan, L. L., Beauchemin, K. A., \& Oba, M. (2009). Effect of dietary forage to concentrate ratio on volatile fatty acid absorption and the expression of genes related to volatile fatty acid absorption and metabolism in ruminal tissue. Journal of Dairy Science, 92(6), 2767-2781. doi: 10. 3168/jds.2008-1716

Playne, M. J. (1985). Determination of ethanol, volatile fatty acids, lactic and succinic acids in fermentation liquids by gas chromatography. Journal of the Science of Food and Agriculture, 36(8), 638-644. doi: $10.1002 /$ jsfa.2740360803

Poudel, P., Froehlich, K., Casper, D. P., \& St-Pierre, B. (2019). Feeding essential oils to neonatal holstein dairy calves results in increased ruminal prevotellaceae abundance and propionate concentrations. Microorganisms, 7(5), 120. doi: 10.3390/microorganisms 7050120

Ribeiro, P. R., Castro, R. D. de, \& Fernandez, L. G. (2016). Chemical constituents of the oilseed crop Ricinus communis and their pharmacological activities: a review. Industrial Crops and Products, 91, 358-376. doi: 10.1016/j.indcrop.2016.07.010

Schären, M., Drong, C., Kiri, K., Riede, S., Gardener, M., Meyer, U.,... Dänicke, S. (2017). Differential effects of monensin and a blend of essential oils on rumen microbiota composition of transition dairy cows. Journal of Dairy Science, 100(4), 2765-2783. doi: 10.3168/jds.2016-11994

Sniffen, C. J., O’Connor, J. D., Van Soest, P. J., Fox, D. G., \& Russell, J. B. (1992). A net carbohydrate and protein system for evaluating cattle diets: I. Ruminal fermentation. Journal of Animal Science, 70, 35623577. doi: 10.2527/1992.70113562x

Tak, J. H., \& Isman, M. B. (2015). Enhanced cuticular penetration as the mechanism for synergy of insecticidal constituents of rosemary essential oil in Trichoplusia ni. Scientific Reports, 5, 1-10. doi: 10. 1038/srep12690
Teobaldo, R. W., Paula, N. F. de, Zervoudakis, J. T., Fonseca, M. A., Cabral, L. S., Martello, H. F.,... Mundim A.T. (2020). Inclusion of a blend of copaiba, cashew nut shell and castor oil in the protein-energy supplement for grazing beef cattle improves rumen fermentation, nutrient intake and fibre digestibility. Animal Production Science, 60(8), 1039-1050. doi: 10.1071/AN18725

Tomkins, N. W., Denman, S. E., Pilajun, R., Wanapat, M., McSweeney, C. S., \& Elliott, R. (2015). Manipulating rumen fermentation and methanogenesis using an essential oil and monensin in beef cattle fed a tropical grass hay. Animal Feed Science and Technology, 200(1), 25-34. doi: 10.1016/j.anifeedsci. 2014.11.013

Torres, R. N. S., Moura, D. C., Ghedini, C. P., Ezequiel, J. M. B., \& Almeida, M. T. C. (2020). Metaanalysis of the effects of essential oils on ruminal fermentation and performance of sheep. Small Ruminant Research, 189, 106148. doi: 10.1016/j. smallrumres.2020.106148

Van Soest, P. J., Robertson, J. B., \& Lewis, B. A. (1991). Methods for dietary fiber, neutral detergent fiber, and nonstarch polysaccharides in relation to animal nutrition. Journal of Dairy Science, 74(10), 35833597. doi: 10.3168/jds.S0022-0302(91)78551-2

Wang, L., Zhang, G., Li, Y., \& Zhang, Y. (2020). Effects of high forage/concentrate diet on volatile fatty acid production and the microorganisms involved in VFA production in cow rumen. Animals, 10(2), 1-12. doi: 10.3390/ani10020223

Williams, C. H., David, D. J., \& Iismaa, O. (1962). The determination of chromic oxide in feces samples by atomic absorption spectrophotometry. The Journal of Agricultural Science, 59(3), 381. doi: 10.1017/S0 02185960001546X 